'summon' or 'invoke.' With the simple acc. of the person it means 'speak to'; with an inf. added, 'to bid.' Two reff. are indeed given by $\mathrm{L}$. and $\mathrm{S}$. for the meaning ' invoke,' but in each case an inf. is added and the meaning is 'bid.' Moreover, there is no question here of other helpers than the gods. It seems to me probable that

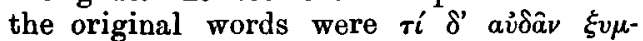

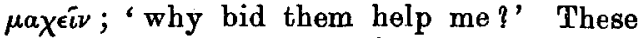
words, plainly implying that she had asked the gods to help her, would naturally be altered when that appeal was excised. The connexion with what follows now becomes clear: "What use to appeal to the gods when they' have allowed me to be called impious for a deed done in their service ?'

M. A. BAYFIELD.

\title{
APHRODITE PANDEMOS AND THE HIPPOLYTUS OF EURIPIDES.
}

Euripides, in the prologue to the Hippolytus, connects the story of his hero and of Phaedra with the erection of a certain statue of Aphrodite at Athens, and with the title or titles which this statue commonly bore. The statue was evidently the Aphrodite $\dot{\epsilon} \pi i$ 'I $\pi \pi \sigma \lambda \dot{v} \tau \omega$, a title known to us from other evidence. It has generally been supposed, and in my opinion rightly, to be identical with the Aphrodite Pandemos, so that

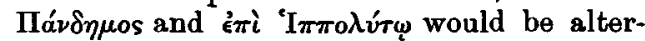
native names; or parts of a single name. Such, for example, is the view adopted by Miss Harrison in the Mythology and Monuments of Ancient Athens. Recently however a distinction has been attempted, and it has been maintained that the sanctuary and cult of the Aphrodite Pandemos, properly and officially so called, were different from the sanctuary and cult of the Aphrodite $\dot{\epsilon} \pi \grave{\imath}$ 'I $\boldsymbol{\pi} \pi 0 \lambda \dot{\tau} \tau \boldsymbol{\omega}$. Materials for considering this question are given by Dr. Frazer in his commentary on Pausanias (1. 22. 1-3). I do not propose to discuss it here, and will assume, for the present purpose, no more than this, that between the Aphrodite émi 'I $\pi \pi 0 \lambda v v^{\prime} \omega$ and the title Pandemos there was for some reason a close association. This much at least the passage of Pausanias (which, in my opinion, presumes the identity) must be held to presume and prove; nor indeed am I aware that it has been disputed. What I propose to show is, that the story told by Euripides is based upon this association; that he assumes his Aphrodite érì 'I $\pi \pi 0 \lambda u ́ v \omega$ to be at least an Aphrodite Pandemos, representing the goddess in that aspect, and commonly connected with that appellation; and that in this connexion of thought is to be found the solution of a certain difficulty which the story presents.

Hippolytus, says Aphrodite, is destined No. CXXXYII. VoL. XV. to expiate his defiance of her, and the way is prepared :

\begin{tabular}{|c|}
\hline 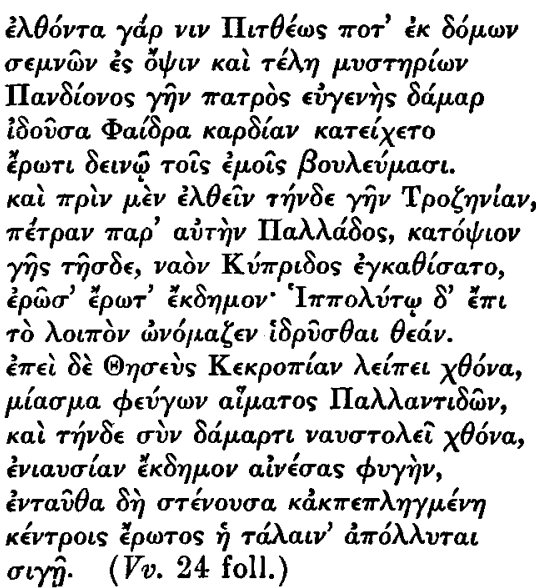 \\
\hline
\end{tabular}

Phaedra gave her Aphrodite a name, $\dot{\omega} \nu \operatorname{ó}_{\mu a \zeta \epsilon}$

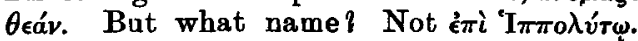
It cannot be meant that she published, by her own act and declaration, the very passion which she desired to conquer, suppress, and conceal. Not Pandemos ; for that title, however it be interpreted, has in this application no meaning and cannot be found in the words. Such is the difficulty.

It has been proposed to get rid of it by so changing the text that the title meant (which is assumed to be $\dot{\epsilon} \pi \imath^{\prime} \mathrm{I} \pi \pi 0 \lambda \dot{v} \tau \omega$ ) shall not be bestowed by Phaedra, but by some one else. Such is the principle of Jortin's emendation,

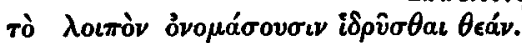

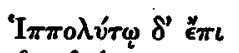

- men hereafter shdll name the statue

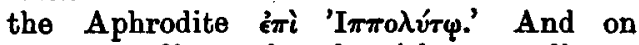
the same lines, though with more discreo $\mathrm{O}$ 
tion and better taste, proceeds that of

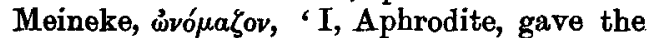
name.' But not even this will pass. At the time when Aphrodite speaks, at the dramatic time of the prologue, the name $\dot{\epsilon} \pi i{ }^{\prime}\left[\pi \pi 0 \lambda v^{\prime} \omega\right.$ has manifestly not yet been attached to the statue; the goddess may intend that it shall be attached; but this is

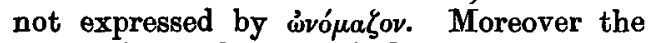
matter in hand is the feeling and purpose of Phaedra, when the dedication was made; if the name in question was not then given by her, this is no place to mention it; both

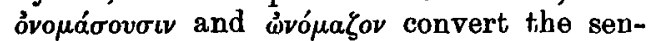
tence into a mere parenthesis, offensive in such a story and at such a point. In fact this road leads nowhere; the conferring of

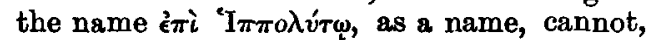
from the nature of the case, be that which the poet has here directly in view. If any way is to be found, we must start afresh.

The difficulty arises, as I think, from the fact that Euripides, repeating a legend which, whatever it was, must have been familiar to his audience, has told it, as a poet in such circumstances would, allusively ; so that a certain point in it, though necessary and central, is not so much stated as implied. The legend did actually explain how the statue came by the description $\dot{\epsilon} \pi \grave{\imath}$ 'I $\pi \pi 0 \lambda v v^{\prime} \omega$, and how the goddess came by the title Pandemos; it derived both the description and the title from a name conferred on the statue by Phaedra in dedicating it.

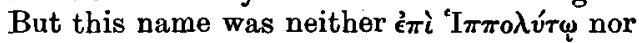
Pandemos. The name which Phaedra gave, but which, with only too much reason, was afterwards changed to another, was $A$ phrodite Endemos or 'Love at Home'. When Hippolytus had returned from Athens to Troezen, Phaedra, finding that her heart had gone after him, and virtuously desiring to be rid of the passion with which Aphrodite had afflicted her, endeavoured to propitiate, and perhaps to control, the goddess by a symbolic offering and ceremony, signifying that she called back her errant affection, and bade it thenceforward abide and dwell in its own place. Because "she was in love

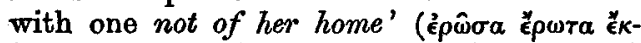

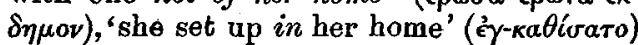
$a$ shrine and figure of the representative goddess, 'and gave the figurea name(Endemos) importing and intending that henceforth for ever the goddess was there fixed' or 'there

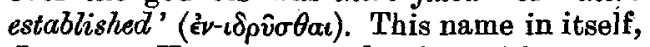
Love at Home, sounded of nothing but innocence and happiness. That she gave it

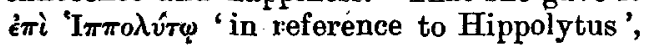
and in the hope to cure herself of an çpws $^{\circ}$ єै $\kappa \delta \eta \mu$ os already kindled in her heart, was her own secret. Thus it was that

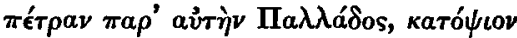

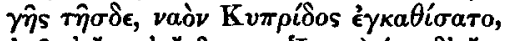

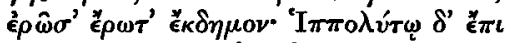

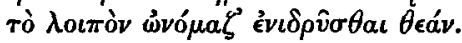

The change, if such it is to be called, of

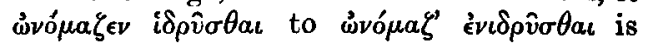
preferable, though perhaps not necessary. However Aphrodite was not to be so appeased or so confined, as soon appeared when, in the course of fate, Theseus himself removed to Troezen, and Phaedra was compelled to share the city and home of Hippolytus, so that her 'Love at Home' in Athens became an idle figure, and its title a miserable irony-a connexion of thought which Euripides, with skilful touch, indicates by contriving, naturally and as if casually, to repeat and echo the significant word

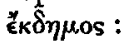

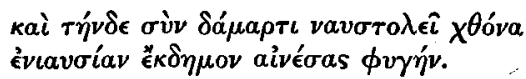

At Troezen the plan of Aphrodite went victoriously forward and her victims perished as the tragedy sets forth. Now when all this came to be known, men drew from it the lesson which Aphrodite meant to teach, that She is not of this place or of that place, not by any title or any figure to be fixed here or there, in Athens or in Troezen; She is of all peoples, of all places and everywhere at home, and Her power is everywhere under heaven (vv. 1-6),

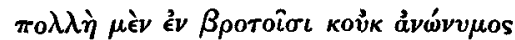

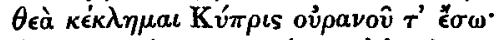

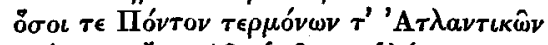

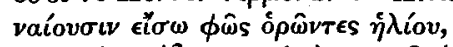

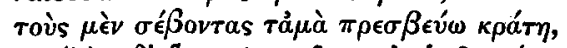

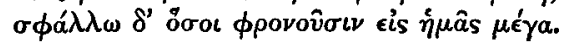

And that Her name might remind men of this, and warn them to bear themselves humbly towards Her, they called Her thenceforward Pandemos; and of the statue, which Phaedra had dedicated in the hope to confine the goddess, and had so ineffectually

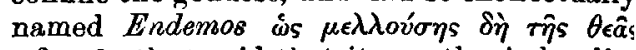

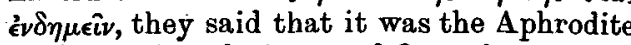

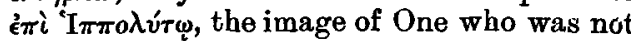
Endemos but Pandemos.

Such was the Athenian legend in the fiftl century B.c., and not an ill one. It has at all events more religion in it, and not less morality, than the philosophic allegory madt famous by Plato, and more interest thai the curiously frigid piece of fictitious histor: 
attached to Pandemos in Pausanias : to wit, that Theseus established the name and calt, in conjunction with that of Peitho, to commemorate his-success in wooing and persuading all the townships ( $\delta \hat{\eta} \mu o \mathrm{~s}$ ) of Attica to unite in one common city. A marriage of united parishes indeed! When paganism was vivid, men had a notion of Aphrodite which certainly was not that.

It may not be superfluous to add, since the Euripidean version, equally with those of Plato, Pausanias and Harpocration, ${ }^{1}$ in explaining the name Pandemos puts a strain upon the word, that none of these stories,

1 Connecting Pandemos locally with the agora. nor whatsoever others the ancients may have related, are relevant to the question, what, if anything, that title, or the descrip.

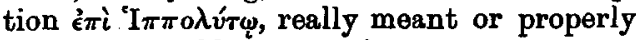
was. It would be unsafe even to assume that the very dialect, in which these appellations were first formed, was what we know as Greek, still more unsafe to assume, that their origin was such as the Greeks or we should consider appropriate, or are able to divine. They were merely names. Of their beginning the Athenians, it is safe to suppose, knew nothing, and we are not likely to know.

A. W. VerralL.

\section{ON THE FRAGMENTS OF THE MINOR TRAGEDIANS.}

\section{(NadCk's Numeration.)}

Achaeus. fr. 4, 4 :

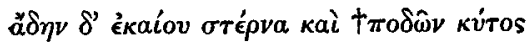

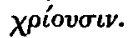

Read $\pi \nu$ o $\hat{\omega} \nu$ кútos (" the chest ').

Fr. adesp. 497 :

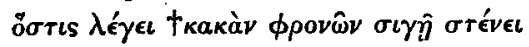

Read

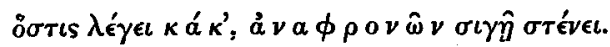

Fr. adesp. 112 :

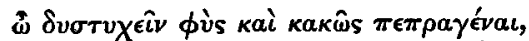

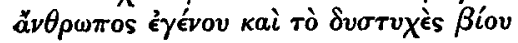

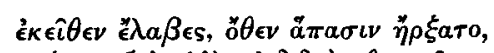

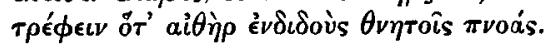

With this punctuation the only error lies in

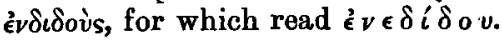

Fr. adesp. 473 :

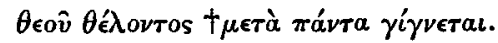

Probably $\mu \in \sigma \tau$ à.

Chaerem. fr. 13 :

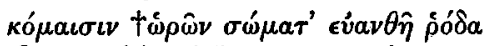

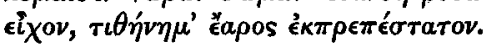

$I$ suggest $\dot{\omega} \rho \hat{t} \sigma \mu a \tau^{\prime}$.

T. G. TUCKER.

\section{THE 'DELIBERATIVE' INDICATIVE.}

IN his paper upon 'Method in Study of the Modes' 1 Mr. H. C. Nutting posits as 'a general principle' of this investigation that other aspects of the speech-form than the mode of the verb may be the essential features that convey to the hearer those ideas which it is generally felt to be the province of mode to express, e.g., deliberation, ${ }^{2}$ taking as his text the mood in quid ago? 'what am I to do?' I have more than once pointed out the mischief which is caused by the use of the term 'Deliberative' for the mood in such sentences: and here is another example. There is 'deliberation' indeed in the sen-

1 Classical Review, Nov., pp. 420 sqq.

2 The italics are Mr. Nutting's. tence; but none in the mood. The deliberation is in the question. One might as well say that there is an 'interrogative indicative' and cite as an example quis est? The truth is that quid ago? asks a question about a contemplated future action (that should be or may be taken by the speaker); and it is this which the mood expresses or as Mr. Nutting thinks, fails to express. The confusion, whether of thought or expression, does not however matter so much here, as it is at least doubtful whether the mood in these sentences is really indicative at all. I have long suspected it of being subjunctive. No doubt the Roman of Classical times would not have regarded 